\title{
The Moderating Effect of the High Involvement Work Systems Between the Relationship of Role Overload and Organizational Citizenship Behavior in Apparel Industry
}

\section{(Special Reference to Katunayake Free Trade Zone)}

\author{
J.K.K.N. Jayakody ${ }^{1}$ \& B.M. Wijesiri ${ }^{2}$ \\ ${ }^{1,2}$ Department of Business Management \\ Faculty of Business Studies \& Finance \\ Wayamba University of Sri Lanka \\ Kuliyapitiya \\ SRI LANKA \\ $\underline{\text { kavindi.narmada.123@gmail.com }}$,
}

\begin{abstract}
This study attempted to examine the moderating effect of the high involvement work systems between the relationship of role overload and organizational citizenship behavior in apparel industry. Furthermore, this study examined the relationship between length of service and organizational citizenship behaviour also. Role overload is normal condition among sewing associates in garment field and it is inherent to the industry. The whole organizational success critically lies on the hands of sewing associates. So, it is very important to study, how to minimize negative effect of role overload on organizational citizenship behaviour by implementing a sound high involvement work system. This study followed deductive research approach and conducted among 300 sewing associates from five garment factories in Katunayake free trade zone using a questionnaire. Findings indicated that the negative relationship between role overload and organizational citizenship behaviour is moderated by high involvement work systems and there was a positive relationship between role overload and length of service of the employees.
\end{abstract}

Keywords: Apparel Industry, High Involvement Work System, Organizational Citizenship Behaviour, Role Overload.

\section{INTRODUCTION}

The challenge of global competition highlights the importance of the concepts such as innovation, flexibility responsive to everlasting change. Organizations seek new areas for sustainable competitive advantage.
Human resources are the most crucial factor to create advantage that cannot be easily duplicated by rivals and specific for each organization. Work behaviors like organizational citizenship behaviors (OCBs) are receiving more attention as they contribute to effective functioning of 
organization. OCB, also stated as extra-role performance, is defined as individual behavior that is discretionary, not directly or explicitly recognized by the formal reward system, and that in the aggregate promotes the effective functioning of the organization (Organ, 1988).

Employees at times exhibit certain behaviours that go beyond the call of the duty. Role overload is the situation in which individual have to meet the high demands of roles, obligations or tasks that need to be fulfilled within a specific period of time and it is more than what they could perform (Rizzo et al.,1970). HPWS are a set of practices that typically comprise comprehensive recruitment and selection, incentive-based compensation, performance management, extensive employee involvement, and detailed training initiatives (Huselid, 1995). Besides looking at the direct effect between role overload and OCB, the moderating role of high involvement work systems (HIWS) on this relationship was examined. OCB has been shown to have a considerable positive impact on organizational levels of productivity, efficiency and customer satisfaction, enhancing organizational effectiveness.

In addition, OCB is linked to lower rates of employee turnover and absenteeism (Podsakoff et al., 2000). The subject matter which has been subjected to this research popup with the reported abnormal labour turnover rate, absenteeism, and increasing complains directed to employee council by expressing displeasure against Sunday working, abnormal work load and overtime hours. Evidences are collected from apparel industry that shows increasing trend in turnover which exceeded industry accepted rate of $3 \%$, long absenteeism and negative comments which had been directed to employee council to express displeasure about extra working dates and abnormal work load and OT hours. These all indirect forces represent disfavor regarding performance of job role which has been described in job description even.

Previous studies provide contradictory evidence regarding the relationship between multiple job demands (Coverman, 1989). One of those job demands is role overload and can be defined as the feeling of employees that their work roles are overloaded (Jensen, Patel, \& Messersmith, 2013). In addition, role overload is a dimension of job demands of the job demands-resources model (JD-R model). Job demands refer to those physical, psychological, social, or organizational aspects of the job that require sustained physical and/or psychological (cognitive and emotional) effort (Bakker, Demerouti, $\&$ Verbeke, 2004). According to Farh, Podsakoff and Organ (1990), role overload has a significant negative relationship with OCB. Based on the literature of Ramsay, Scholarios and Harley (2000) and the Conservation of Resources (COR) theory, it is expected that HIWS will influence the relationship between role overload and OCB negatively, because it will strengthen the feeling of role overload on employees who already feel overloaded instead of enhance 
employees' levels of skill, motivation, information and empowerment.

So, through this research researcher expect to investigate how role overload effect on organizational citizenship behaviour with the moderating effect of high involvement work systems.

This study attempted to address the following questions:

a) To what extent does role overload influence organizational citizenship behaviour?

b) How is the relationship between role overload and organizational citizenship behaviour moderated by high involvement work systems?

c) To what extent does length of service influence organizational citizenship behaviour?

Having considered the research questions stated above, and also the significance of the present research, the following objectives were determined.

a) Identify the extent to which role overload influence organizational citizenship behaviour.

b) Identify the relationship between role overload and organizational citizenship behaviour moderated by high involvement work systems.

c) Identify the extent does length of service influence organizational citizenship behaviour.
This is useful for employees, organizations and society because in this way, jobs can be adapted accordingly and employees will be able to show more OCB which leads to higher organizational effectiveness which ultimately also benefits the employees and society overall (McKenzie, Podsakoff, \& Fetter, 1993; Podsakoff et al.,

2000). Furthermore, investigating the moderating effect of high involvement work system (HIWS) will give new insights on how the use of human resource (HR) systems can decrease the effect of role overload on the level of OCB in organizations.

\section{METHOD}

This study involved with the deductive approach and has derived hypotheses based upon the conceptual framework which is based on literature.

The sample of the study consisted of 300 operational level employees by using Morgan table out of 2000 sewing associates under 95\% confidence level. The sampling design consisted of stratified sampling. Survey was selected as suitable for this research study where a questionnaires distributed to gather a large volume of data in a costeffective manner within a short time period.

The study made use of data from both primary and secondary sources. Primary data about organizational citizenship behaviour, role overload and high involvement work systems from the employee's perspective has been collected through questionnaire. 
The secondary data related to the above subject matter was

collected from the other research

findings who already investigated and books.

After the data gathering, researcher analyzed data in terms of align with the objectives of the study already proposed. Data were analyzed by using statistical package for social science; SPSS version 20 tool. To measure the reliability and validity in this study the researcher uses "Cronbach's Alpha" separately for each variable. To test the normality the researcher used Skewness Coefficient for both independent variables and dependant variable drivers. In this study, data is categorical and not normally distributed. Therefore, examination should be done with the One-Way ANOVA and Chi - Square test results, (Gujarati and Porter 2009). Spearman rank-order correlation analysis was used in this study with respectively to nature of the variables to measure the strength of that relationship with available statistical data. A multiple linear regression will be performed to find the effect between the individual constructs is significant or not. Regression analysis includes many techniques to analyse the relationship between dependent variable and independent variables. $\mathrm{R}^{2}$ value suggests that total variation of dependent variable is explained by independent variable. F-value suggests the suitability of the regression formula.

\section{RESULTS}

This section comprises with the findings of the study; provides answers to the research questions in line with the objectives of the research.

H1: The higher the employees' levels of role overload, the lower their organizational citizenship behaviour.

Table 1. Correlation Test Result

\begin{tabular}{|c|c|c|c|c|}
\hline \multicolumn{5}{|c|}{ Correlations } \\
\hline & & & $\begin{array}{l}\text { Qrganiza } \\
\text { tional } \\
\text { Citizens } \\
\text { hip } \\
\text { Behavio } \\
\text { ur }\end{array}$ & $\begin{array}{c}\text { Role } \\
\text { Oxerloa } \\
\text { d }\end{array}$ \\
\hline \multirow[t]{6}{*}{$\begin{array}{l}\text { Spear } \\
\text { man's } \\
\text { rho }\end{array}$} & \multirow{3}{*}{$\begin{array}{l}\text { Organiza } \\
\text { tional } \\
\text { Citizens } \\
\text { hip } \\
\text { Behavia } \\
\text { w }\end{array}$} & $\begin{array}{l}\text { Correl } \\
\text { ation } \\
\text { Coesffi } \\
\text { cient. }\end{array}$ & 1.000 & $-.765^{4 *}$ \\
\hline & & $\begin{array}{l}\text { Sig. } \\
\text { (2- } \\
\text { tailed) }\end{array}$ & & .000 \\
\hline & & $\mathrm{N}$ & 300 & 300 \\
\hline & \multirow[t]{3}{*}{$\begin{array}{l}\text { Role } \\
\text { Overload }\end{array}$} & $\begin{array}{l}\text { Correl } \\
\text { ation } \\
\text { Coesffi } \\
\text { cient. }\end{array}$ & $-.765^{* 4}$ & 1.000 \\
\hline & & $\begin{array}{l}\text { Sig. } \\
\text { (2- } \\
\text { tailed) }\end{array}$ & .000 & \\
\hline & & $\mathrm{N}$ & 300 & 300 \\
\hline
\end{tabular}

Table 1 presents the correlation test result between the organizational citizenship behaviour and role overload.

According to the Spearman rank-order correlation analysis the role overload is strongly negatively correlated ((Correlation Coefficient is - 0.765) and (Sig. (2-tailed)) is 0.000)) with on organizational citizenship behaviour in apparel industry at $05.00 \%$ level of significance. 
H2: The negative relationship between role overload and organizational citizenship behaviour is moderated by high involvement work systems.

\section{Table 2. Correlation Test Result}

\begin{tabular}{|c|c|c|c|c|}
\hline \multicolumn{5}{|c|}{ Correlations } \\
\hline & & & $\begin{array}{c}\text { Organiza } \\
\text { tional } \\
\text { Citizensh } \\
\text { in } \\
\text { Behayia } \\
\text { ur }\end{array}$ & $\begin{array}{c}\text { Role } \\
\text { Qxerloa } \\
\text { dx } \\
\text { High } \\
\text { Involve } \\
\text { ment } \\
\text { Work } \\
\text { System } \\
\end{array}$ \\
\hline \multirow[t]{6}{*}{$\begin{array}{l}\text { Spear } \\
\text { man's } \\
\text { rho }\end{array}$} & \multirow{3}{*}{$\begin{array}{l}\text { Organiza } \\
\text { tional. } \\
\text { Citzzensh } \\
\text { in } \\
\text { Behaxia } \\
\text { ur }\end{array}$} & $\begin{array}{l}\text { Conrel } \\
\text { ation } \\
\text { Coeffi } \\
\text { cient. }\end{array}$ & 1.000 & $-.480^{* *}$ \\
\hline & & $\begin{array}{l}\text { Sig. (2- } \\
\text { tailed) }\end{array}$ & & .000 \\
\hline & & $\mathrm{N}$ & 300 & 300 \\
\hline & \multirow{3}{*}{$\begin{array}{l}\text { Role } \\
\text { Overload } \\
\text { x High } \\
\text { Involve } \\
\text { ment } \\
\text { Work } \\
\text { System }\end{array}$} & $\begin{array}{l}\text { Correl } \\
\text { ation } \\
\text { Coefffi } \\
\text { cient. }\end{array}$ & $-.480^{* *}$ & 1.000 \\
\hline & & $\begin{array}{l}\text { Sig. (2- } \\
\text { tailed) }\end{array}$ & .000 & \\
\hline & & $\mathrm{N}$ & 300 & 300 \\
\hline
\end{tabular}

Table 2 presents the correlation test result between the organizational citizenship behaviour and role overload $\times$ high involvement work system

According to the Spearman rank-order correlation analysis, role overload $\mathrm{x}$ high involvement work system is negatively correlated ((Correlation Coefficient is - 0.480) and (Sig. (2tailed)) is 0.000)) with on organizational citizenship behaviour in apparel industry at $05.00 \%$ level of significance.

Further, role overload $\mathrm{x}$ high involvement work system is weakly negatively correlated with organizational citizenship behaviour in apparel industry. It indicates; the high involvement work system is decreased the negative effect of the role overload on the organizational citizenship behaviour in apparel industry. Therefore, there is a moderating effect of the high involvement work system between the relationships of the role overload and the organizational citizenship behavior in apparel industry (Special reference to Katunayake free trade zone).

H3: The higher the employees' length of service, the higher their organizational citizenship behavior.

Table 3. Correlation Test Result

\begin{tabular}{|c|c|c|c|c|}
\hline \multicolumn{5}{|c|}{ Correlations } \\
\hline & & & $\begin{array}{l}\text { Qrganizat } \\
\text { ional } \\
\text { Citizensh } \\
\text { in. } \\
\text { Behayiou } \\
\text { r }\end{array}$ & $\begin{array}{l}\text { Lengt. } \\
h \text { of } \\
\text { Servi } \\
\text { ce. }\end{array}$ \\
\hline \multirow[t]{6}{*}{$\begin{array}{l}\text { Spearm } \\
\text { an's rho }\end{array}$} & \multirow{3}{*}{$\begin{array}{l}\text { Qrganizat } \\
\text { ional } \\
\text { Citizensh } \\
\text { id } \\
\text { Behayiou } \\
\text { r }\end{array}$} & $\begin{array}{l}\text { Correla } \\
\text { tion } \\
\text { Coefficic } \\
\text { ient }\end{array}$ & 1.000 & $\begin{array}{r}938^{*} \\
*\end{array}$ \\
\hline & & $\begin{array}{l}\text { Sig. (2- } \\
\text { tailed) }\end{array}$ & & .000 \\
\hline & & $\mathrm{N}$ & 300 & 300 \\
\hline & \multirow[t]{3}{*}{$\begin{array}{l}\text { Length of } \\
\text { Service }\end{array}$} & $\begin{array}{l}\text { Correla } \\
\text { tion } \\
\text { Coefficic } \\
\text { ient }\end{array}$ & $.938^{* *}$ & 1.000 \\
\hline & & $\begin{array}{l}\text { Sig. (2- } \\
\text { tailed) }\end{array}$ & .000 & \\
\hline & & $\mathrm{N}$ & 300 & 300 \\
\hline
\end{tabular}

Table 3 presents the correlation test result between the organizational citizenship behaviour and length of service. 
According to the Spearman rank-order correlation analysis, length of service is strongly positively correlated ((Correlation Coefficient is 0.938) and (Sig. (2-tailed)) is 0.000)) with organizational citizenship behaviour in apparel industry at $05.00 \%$ level of significance.

Table 4. Model Summary

\begin{tabular}{|c|c|c|c|c|}
\hline \multicolumn{5}{|c|}{ Model Summary ${ }^{b}$} \\
\hline Model & $\mathrm{R}$ & $\begin{array}{c}\mathrm{R} \\
\text { Square }\end{array}$ & $\begin{array}{c}\text { Adjusted } \\
R \\
\text { Square }\end{array}$ & $\begin{array}{c}\text { Std. } \\
\text { Error of } \\
\text { the } \\
\text { Estimate }\end{array}$ \\
\hline 1 & $.901^{\mathrm{a}}$ & .812 & .811 & .11874 \\
\hline \multicolumn{5}{|c|}{$\begin{array}{l}\text { a. Predictors: (Constant), Length of Service, Role } \\
\text { Overload }\end{array}$} \\
\hline \multicolumn{5}{|c|}{$\begin{array}{l}\text { b. Dependent Variable: Organizational } \\
\text { Citizenship Behaviour }\end{array}$} \\
\hline
\end{tabular}

Table 4 presents the model summary without the moderating effect of the high involvement work system

According to the table of model summary, the selected independent variables are explained the total variation of the organizational citizenship behaviour: a case of Sri Lanka by $81.10 \%$.

\section{Table 5. Regression Coefficients}

\begin{tabular}{|c|c|c|c|c|c|c|}
\hline \multicolumn{7}{|c|}{ Coefficients ${ }^{\mathbf{a}}$} \\
\hline \multirow{2}{*}{\multicolumn{2}{|c|}{ Model }} & \multicolumn{2}{|c|}{$\begin{array}{l}\text { Unstandardiz } \\
\text { ed. } \\
\text { Coefficients }\end{array}$} & $\begin{array}{c}\text { Stan } \\
\text { dard } \\
\text { ized } \\
\text { Coef } \\
\text { ficie } \\
\text { nts }\end{array}$ & \multirow[b]{2}{*}{$t$} & \multirow[b]{2}{*}{ Sig. } \\
\hline & & B & $\begin{array}{l}\text { Std. } \\
\text { Erre } \\
1\end{array}$ & Beta & & \\
\hline \multirow[t]{4}{*}{1} & $\begin{array}{l}\text { (Const } \\
\text { ant) }\end{array}$ & 3.073 & .168 & & 18.347 & .000 \\
\hline & Role & & & & & \\
\hline & $\begin{array}{l}\text { Qwerlo } \\
\text { ad }\end{array}$ & -.268 & .042 & -.246 & -6.314 & .000 \\
\hline & $\begin{array}{l}\text { Length } \\
\text { of } \\
\text { Servic } \\
\text { e }\end{array}$ & .150 & .008 & .699 & 17.916 & .000 \\
\hline
\end{tabular}

Table 5 present regression coefficients without the moderating effect of the high involvement work system

According to the regression results; the Factors such as role overload and length of service have a significant impact on organizational citizenship behaviour: a case in Sri Lanka at $05.00 \%$ level of significance.

Regression equation for the estimated model without the moderating is

OCBi $=3.073-0.268 \times X 1+0.150 \times$ $\mathrm{X} 2+\varepsilon$

Table 6. Model Summary

\begin{tabular}{|c|c|c|c|c|}
\hline \multicolumn{5}{|c|}{ Model Summary } \\
\hline Model & $\mathrm{R}$ & $\begin{array}{c}\mathrm{R} \\
\text { Square }\end{array}$ & $\begin{array}{l}\text { Adjusted } \\
\text { R Square }\end{array}$ & $\begin{array}{l}\text { Std. } \\
\text { Error of } \\
\text { the } \\
\text { Estimate }\end{array}$ \\
\hline 1 & $.898^{\mathrm{a}}$ & .807 & .805 & .12057 \\
\hline \multicolumn{5}{|c|}{$\begin{array}{l}\text { a. Predictors: (Constant), Length of Service, Role } \\
\text { Overload x High Involvement Work System }\end{array}$} \\
\hline \multicolumn{5}{|c|}{$\begin{array}{l}\text { b. Dependent Variable: Organizational } \\
\text { Citizenship Behaviour }\end{array}$} \\
\hline
\end{tabular}

This presents model summary with the moderating effect of the high involvement work system.

According to the table of model summary, the selected independent variables are explained the total variation of the organizational citizenship behaviour: a case of Sri Lanka by $80.50 \%$. 
Table 7. Regression Coefficients

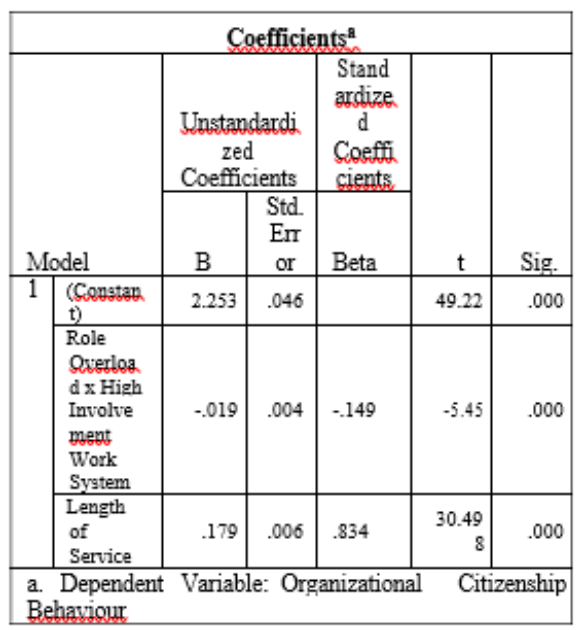

Table 7 presents regression coefficients with the moderating effect of the high involvement work system

Regression coefficients represent the change in the response variable for one unit of change in the independent or predictor variable while holding other predictors in the model are constant.

According to the regression results; the factors such as role overload $\mathrm{x}$ high involvement work system and length of service have a significant impact on organizational citizenship behaviour: a case in Sri Lanka at $05.00 \%$ level of significance.

Regression equation for the estimated model with the moderating effect is

$\mathrm{OCBi}=2.253-0.019 \times \mathrm{X} 1+0.179 \mathrm{x}$ $\mathrm{X} 2+\varepsilon$

\section{DISCUSSION}

According to the Spearman rank-order correlation analysis the role overload is strongly negatively correlated
((Correlation Coefficient is - 0.765) and (Sig. (2-tailed)) is 0.000)) with on organizational citizenship behaviour in apparel industry at $05.00 \%$ level of significance. The reason for -0.765 coefficient is an employee feels, he is suffering from role overload it actually creates a negative impact on the organizational citizenship behaviour. So, it is clear that role overload adversely impacts on organizational citizenship behaviour.

As per the Spearman rank-order correlation analysis, length of service is strongly positively correlated ((Correlation Coefficient is 0.938). Actually, when an employee work for an organization for a long period of time he shows a loyal behaviour towards the organization. If someone settle his employment as a life time employment with the organization actually it creates a strong effect to work as more loyal.

According to the Spearman rank-order correlation analysis, role overload $\mathrm{x}$ high involvement work system is negatively correlated ((Correlation Coefficient is - 0.480) and (Sig. (2tailed)) is 0.000)) with on organizational citizenship behaviour in apparel industry at $05.00 \%$ level of significance. Further, role overload $\mathrm{x}$ high involvement work system is weakly negatively correlated with organizational citizenship behaviour in apparel industry. It indicates; the high involvement work system is decreased the negative effect of the role overload on the organizational citizenship behaviour in apparel industry. Therefore, there is a moderating effect of the high involvement work system between the 
relationships of the role overload and the organizational citizenship behavior in apparel industry (Special reference to Katunayake free trade zone). The reason is, strength of the negative outcomes of role overload is positively moderated by the employee oriented high involvement work system. It tells even though some one is suffering from the role overload, if he is provided benefits and comfort for his work through the high involvement work system, he shows the loyal behaviour. Correlation Coefficient 0.765 is reduced up to -0.480 by implementing high involvement work system.

\section{CONCLUSION}

This study aimed to give insight into the relationship between role overload and OCB and into how HIWS moderates this relationship. This is important because OCB has been shown to have a positive impact on organizational effectiveness (Podsakoff et al., 2000). In addition, OCB is linked to lower rates of employee turnover and absenteeism and on the organizational level it is linked to increased productivity, efficiency and customer satisfaction (Podsakoff et al., 2000).

Even though the mainstream view is that HPWS are beneficial for organizations, an alternative theoretical perspective has developed that challenges the "rhetoric versus reality" of HPWS. This perspective suggests that HPWS, which are aimed at creating a competitive advantage for organizations, do so at the expense of individual employees, thus resulting in role overload, burnout, and heightened pressure for individuals (Godard, 2001，2004; Gould-Williams, 2007; Kroon, van de Voorde \& van Veldhoven, 2009; Ramsay, Scholarios \& Harley, 2000). From this vantage point HPWS may have some deleterious consequences for individual employees. However, we argue that these consequences may be tempered when HPWS are implemented with a sufficient amount of job control, or discretion given to employees in determining how to implement job responsibilities (Karasek, 1979). This study accepts the view of mainstream and contradict to the alternative view by showing positive effect of HIWS.

According to the findings of the study, it is concluded that there is a moderating effect of high involvement work system between the relationship of role overload and organizational citizenship behaviour.

Accordingly, the negative relationship between role overload and organizational citizenship behaviour is moderated by high involvement work systems. And there is a positive relationship between length of service and organizational citizenship behaviour.

And researcher suggest following recommendations for improving organizational citizenship behaviour. In the researcher point of view, role overload in apparel sector can't be totally eliminated. As well as role overload negatively effect on organizational performance in long time and loyalty toward the organization. So, by implementing a high involvement work system 
including green human resource policies and practices which are focused on not only productivity but also on human perspective also. And implementing employees' council in each month as compulsory. This is the occasion for the employees to raise their voice against the problems which has been faced by them and ensure, take immediate decision before it become a dispute with the union intervention and not to take partial decision. It will secure the organizational citizenship behaviour. As well as conduct events which add a value their personal lives also e.g. anti-drug campaigns. And let them to work under flexible work environment. By implementing these kinds of actions, organizations can enhance the organizational citizenship behaviour.

\section{REFERENCES}

Bakker, A. B., Demerouti, E., \& Verbeke, W. (2004). Using the job demands-resources model to predict burnout and performance. Human resource management, 43(1), 83- 104.

Coverman, S. (1989). Role overload, role conflict, and stress: Addressing consequences of multiple roles demands. Social forces, 965-982. doi: $10.2307 / 2579710$.

Farh, J. L., Podsakoff, P. M., \& Organ, D. W. (1990). Accounting for organizational citizenship behavior: Leader fairness and task scope versus satisfaction. Journal of management, 16(4), 705-721.
Godard, J. 2001. High performance and the transformation of work: The implications of alternative work practices for the experience and outcomes of work. Industrial and Labor Relations Review, 54: 776-805.

Gould-Williams, J. S. 2007. HR practices, organizational climate and employee outcomes: Evaluating social exchange relationships in local government. International Journal of Human Resource Management, 18: 1627 1647.

Gujarati,D. N., Porter ,D.C. (2009). Basic Econometrics $5^{\text {th }}$ Edition, McGraw Hill Inc., New York.

Huselid, M. (1995). The impact of human resource management practices on turnover, productivity, and corporate financial performance. Academy of Management Journal, 38(3).

Jensen, J. M., Patel, P. C., \& Messersmith, J. G. (2013). Highperformance work systems and job control: Consequences for anxiety, role overload, and turnover intentions. Journal of Management, 39(6), 1699-1724.

Karasek, R. A. 1979. Job demands, job decision latitude, and mental strain: Implications for job redesign. Administrative Science Quarterly, 24: 285-308.
Kroon, B., van dVoorde, K., \& van Veldhoven, M. 2009. Cross-level effects of 
high-performance work practices and burnout: Two

counteracting mediating mechanisms compared. Personnel Review, 38: 509-525.

MacKenzie, S. B., Podsakoff, P. M., \& Fetter, R. (1993). The impact of Organizational citizenship behaviour on evaluations of sales performance. Journal of Marketing, 57:70-80.

Organ, Dennis W. 1988. Organizational Citizenship Behavior: The Good Soldier Syndrome. Lexington MA: Lexington Books.

Podsakoff, P. M., MacKenzie, S. B., Paine, J.B., \& Bachrach, D. G. (2000). Organizational citizenship behaviors: A critical review of the theoretical and empirical literature and suggestions for future research. Journal of management, 26(3), 513-563. $\begin{array}{cl}\text { Ramsay, } & \text { H., Scholarios, D., } \\ \& & \text { Harley, }\end{array}$ Employees and high-performance work systems: Testing inside the black box. British Journal of Labour Relations, 38: 501- 531.

Rizzo, J. R., House, R. J., \& Lirtzman,S. I. (1970). Role conflict and ambiguity in complex organizations. Administrative Science Quarterly, 15(2), 150-163 